\title{
Northern landscapes in transition: Evidence, approach and ways forward using the Krycklan Catchment Study
}

\author{
Hjalmar Laudon $^{1}$ (i) | Eliza Maher Hasselquist ${ }^{1} \quad$ | Matthias Peichl ${ }^{1} \quad$ | Kim Lindgren ${ }^{1}$ | \\ Ryan Sponseller $^{2}$ | Fredrik Lidman ${ }^{1}$ | Lenka Kuglerová $^{1}$ | Niles J. Hasselquist ${ }^{1}$ | \\ Kevin Bishop $^{3}$ | Mats B. Nilsson ${ }^{1}$ | Anneli M. Ågren ${ }^{1}$ \\ ${ }^{1}$ Department of Forest Ecology and Management, Swedish University of Agricultural Sciences, Umeå, Sweden \\ ${ }^{2}$ Department of Ecology and Environmental Sciences, Umeå University, Umeå, Sweden \\ ${ }^{3}$ Department of Aquatic Sciences and Assessment, Swedish University of Agricultural Sciences, Uppsala, Sweden
}

\section{Correspondence}

Hjalmar Laudon, Department of Forest Ecology and Management, Swedish University of Agricultural Sciences, SE-901 83 Umeå, Sweden.

Email: hjalmar.laudon@slu.se

Funding information

GRIP-for-LIFE and the Kempe Foundation; SKB; Knut and Alice Wallenberg Foundation through Branch-Points and Future Siliviculture; FORMAS; Swedish Research Council (as part of the SITES and ICOS Swedish research infrastructures and project funds); Swedish University of Agricultural Sciences

\begin{abstract}
Improving our ability to detect changes in terrestrial and aquatic systems is a grand challenge in the environmental sciences. In a world experiencing increasingly rapid rates of climate change and ecosystem transformation, our ability to understand and predict how, when, where, and why changes occur is essential for adapting and mitigating human behaviours. In this context, long-term field research infrastructures have a fundamentally important role to play. For northern boreal landscapes, the Krycklan Catchment Study (KCS) has supported monitoring and research aimed at revealing these changes since it was initiated in 1980. Early studies focused on forest regeneration and microclimatic conditions, nutrient balances and forest hydrology, which included monitoring climate variables, water balance components, and stream water chemistry. The research infrastructure has expanded over the years to encompass a 6790 ha catchment, which currently includes 11 gauged streams, ca. 1000 soil lysimeters, 150 groundwater wells, $>500$ permanent forest inventory plots, and a $150 \mathrm{~m}$ tall tower (a combined ecosystem-atmosphere station of the ICOS, Integrated Carbon Observation System) for measurements of atmospheric gas concentrations and biosphere-atmosphere exchanges of carbon, water, and energy. In addition, the KCS has also been the focus of numerous high resolution multi-spectral LiDAR measurements and large scale experiments. This large collection of equipment and data generation supports a range of disciplinary studies, but more importantly fosters multi-, trans-, and interdisciplinary research opportunities. The KCS attracts a broad collection of scientists, including biogeochemists, ecologists, foresters, geologists, hydrologists, limnologists, soil scientists, and social scientists, all of whom bring their knowledge and experience to the site. The combination of long-term monitoring, shorter-term research projects, and large-scale experiments, including manipulations
\end{abstract}


of climate and various forest management practices, has contributed much to our understanding of boreal landscape functioning, while also supporting the development of models and guidelines for research, policy, and management.

\section{KEYWORDS}

boreal region, field research infrastructure, Krycklan Catchment Study, long-term and large scale experiments, long-term monitoring, process-based research

\section{1 | INTRODUCTION}

Water balance, carbon dynamics, and the ecological integrity of northern regions are expected to change in response to global warming. Such changes, in combination with a growing human population, increased environmental pressure, and more intensive resource extraction, will amplify the stressors imposed on terrestrial and freshwater resources in the north. Regardless of whether responses to these combined stressors are gradual or abrupt, the outcome is likely to be unexpected, owing to nonlinearities in catchment-scale storage and release of water, carbon, nutrients, and a wide range of additional processes. Already, a cascade of changes to northern landscapes have been observed in response to shorter and milder winters (Spence et al., 2015) and enhanced summer warming (Isles et al., 2016). Understanding and predicting how this trajectory toward a warmer climate will reshape the physical, chemical, and ecological properties of the natural environment at northern latitudes will be a critical challenge for the scientific community in the decades to come.

High quality empirical data of adequate spatial and temporal resolution are central for deciphering patterns, dynamics, and trends in environmental variables. Catchment hydrology, biogeochemical processes, and landscape carbon balance are inherently complex and often scale dependent, making reliable predictions of future conditions difficult (Laudon \& Sponseller, 2018). Sound predictions are even more challenging in regions where appropriate empirical data to develop, test, and validate models are sparse. Despite the undeniable value of field observations and experiments, a transition from field-based empirical studies to model-only approaches has been an accelerating trend in environmental science (Burt \& McDonnell, 2015). This trend is especially noticeable at northern latitudes, where the number of long-term research sites have declined rapidly during the last decades, leaving only a few locations that generate sufficient empirical data to answer the most pertinent questions about the future of our water resources (Laudon et al., 2017).

Most changes caused by anthropogenic forcing will be superimposed on natural variability that can mask or delay responses and make changes difficult to detect and mechanistically explain. Unravelling the processes responsible for various degrees of environmental perturbations in northern ecosystems therefore requires more than just basic monitoring information, standard models, and insights from other regions. The boreal region is dominated by nutrient limited forests and peatlands representing large carbon stores (Loisel et al., 2014) that combined contain at least a third of the Earth's soil carbon pool (Bradshaw \& Warkentin, 2015). Despite their global importance and vulnerability to ongoing climate change, boreal catchments have been subject to comparatively little experimental, integrative, and process-oriented research in the past (Song et al., 2019). This knowledge-gap is of concern, yet at the same time represents a tremendous opportunity for cutting edge research on global warming feedbacks to both the atmosphere and water resources.

Most stream hydrological and biogeochemical research is based on individual, well-studied catchments, or alternatively on data from regional monitoring datasets. While a major advantage of small research catchments is the large amount of ancillary data that can provide mechanistic insights, a disadvantage is that the results are often based on limited replication and provide poor geographic representation. Conversely, a limitation of environmental monitoring is that data collection is often not designed to answer process-oriented questions, which can make it difficult to infer causal relationships. To overcome the constraints of both approaches, one way forward is to combine the strengths of these two approaches into a framework that promotes basic research in longterm monitored catchments (Tetzlaff et al., 2017), especially when they include several catchments of different scales and land-use (Laudon \& Sponseller, 2018). The heterogeneity inherent to boreal landscapes provides a unique template in this context because of the large spatial variability in the coverage of forests and peatlands that regulates much of the spatial and temporal complexity of soils, hydrology, and biogeochemistry (Fork et al., 2020; Laudon et al., 2011). The study of stream networks also makes it possible to assess the influence of more seldomly studied headwaters to downstream ecosystems (Bishop et al., 2008).

Understanding the role of thresholds, tipping points, and other nonlinear processes is crucial for assessing the consequences of future environmental change. Detecting these responses requires field studies that go well beyond standard, disciplinary approaches. Instead, what is needed for solving many future challenges are research infrastructures that combine field measurements from a multitude of disciplines in the same catchment. This type of effort goes well beyond what one research project or research group can achieve, and requires a well-coordinated infrastructure that can support and combine the collection of critical long-term monitoring data, provide large sets of ancillary empirical information, and host complementary long-term/ large-scale experiments that are crucial to achieving mechanistic understanding of ecosystem responses to environmental change.

While long-term, process-based research at the landscape scale is clearly needed to address the influence of environmental perturbation on terrestrial and aquatic resources, few research sites exist that capture the spatial and temporal dimensions required. One existing 
example is the Krycklan Catchment Study (KCS), located in northern Sweden, which has provided a unique opportunity for integrated, process-based research in the boreal region for decades (Laudon et al., 2013). The over-arching objectives of KCS are to (1) provide a state-of-the-art infrastructure for experimental and hypothesis driven research, (2) maintain a collection of high quality, long-term climatic, biogeochemical, hydrological, and other environmental data, and (3) support the development of models and guidelines for research, policy and management. An important step in this direction is to make the field infrastructure even more visible for potential users at the same time as we make more of the field data openly accessible.
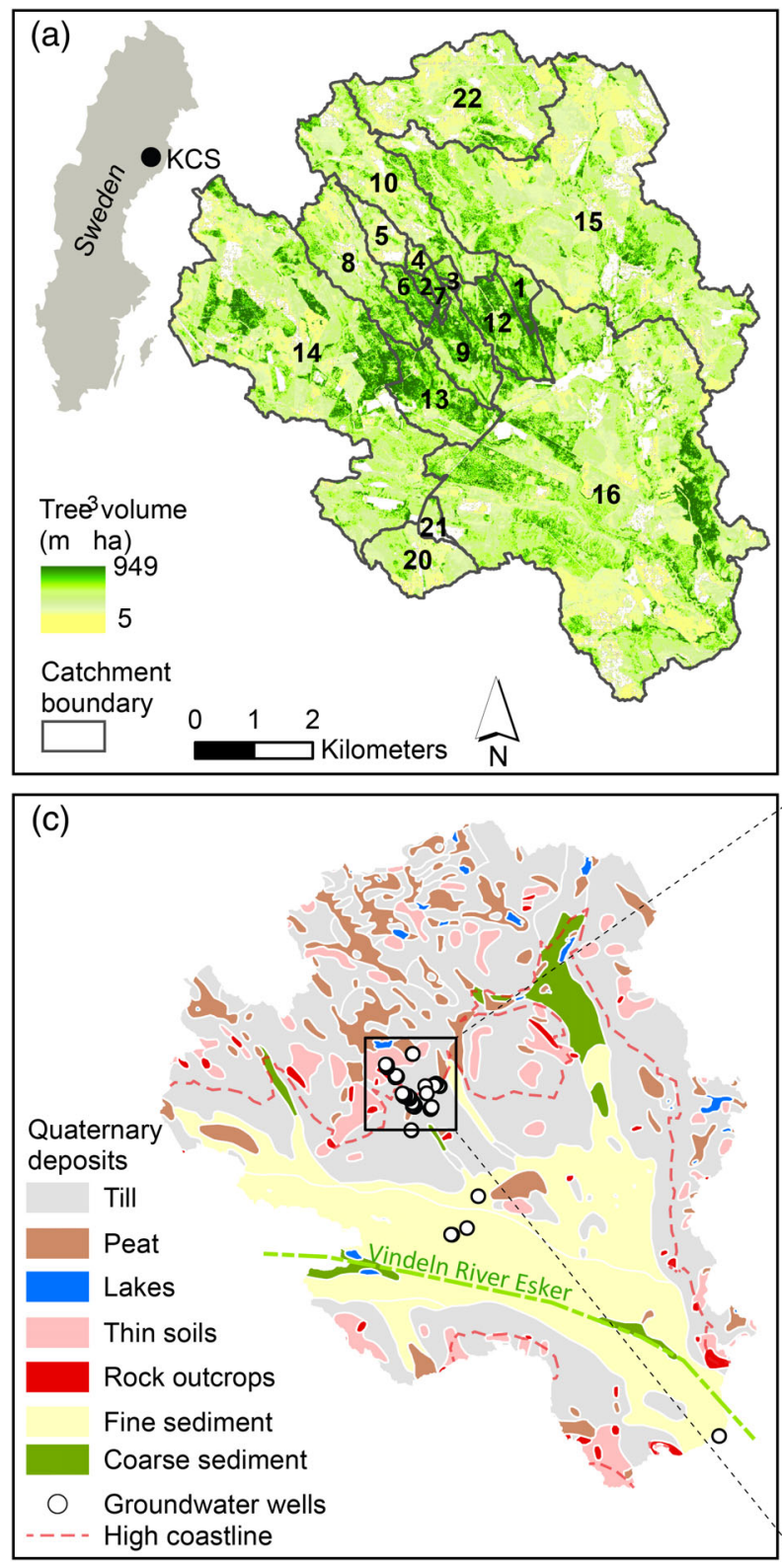

\section{SITE DESCRIPTION}

The Krycklan Catchment Study (KCS, www.slu.se/Krycklan) is located in the heart of the boreal landscape $\left(64^{\circ} 14^{\prime} \mathrm{N}, 19^{\circ} 46^{\prime} \mathrm{E}\right)$, approximately $50 \mathrm{~km}$ northwest of the city of Umeå in northern Sweden (Laudon et al., 2013). The KCS is 6790 ha in area and comprises a mosaic of instrumented and well-studied forests, wetlands, and lakes, all drained and connected by a network of streams and rivers (Figure 1). Over the past 35 years, the existing field research infrastructure has generated data resulting in approximately 1000 peerreviewed publications, and over $110 \mathrm{PhD}$ theses in diverse areas such as hydrology, biogeochemistry, carbon dynamics, climate change,
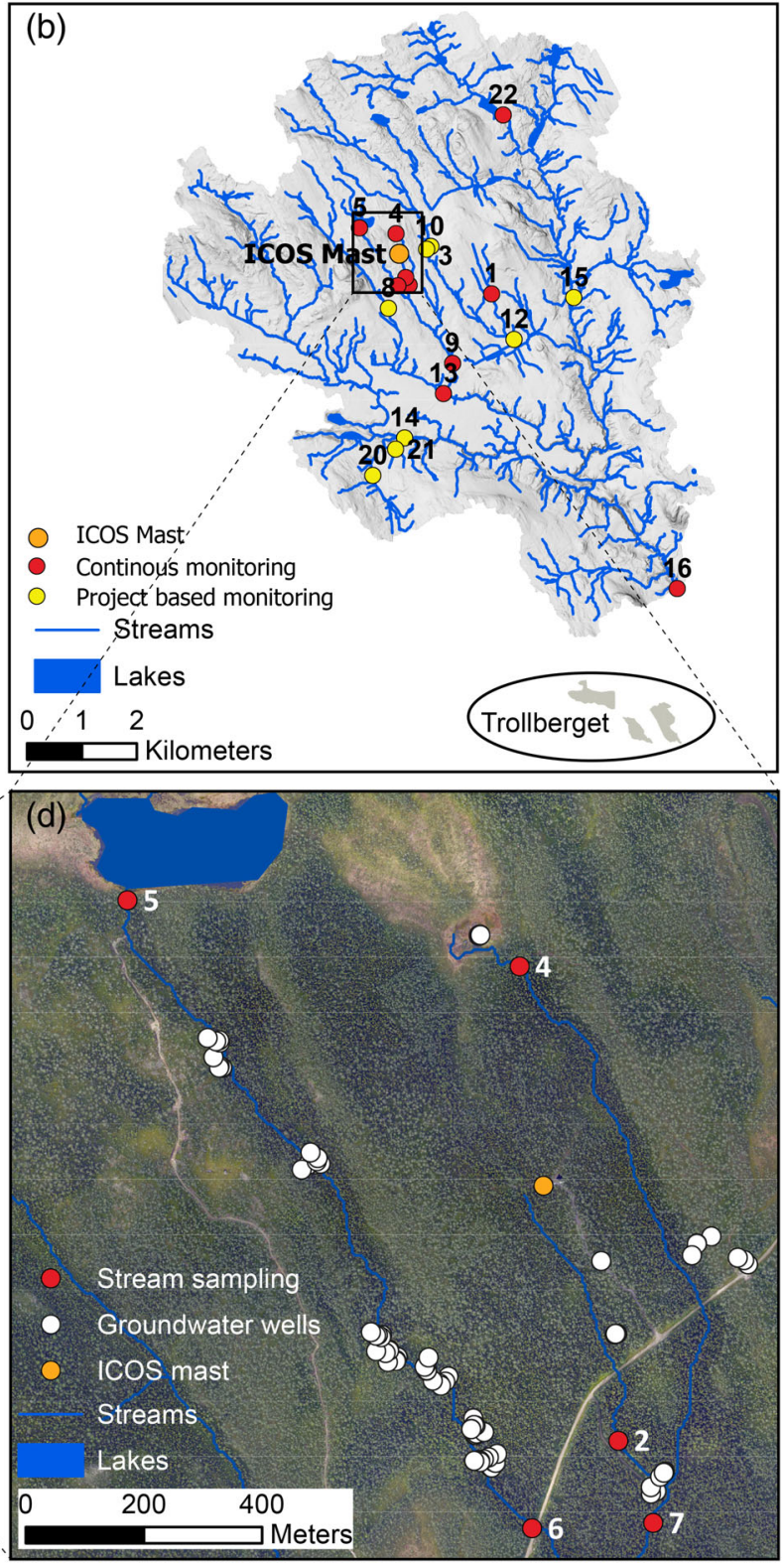

FIGURE 1 The Krycklan Catchment Study shown with sub-catchment areas and corresponding tree density (panel a), the stream network, including the Trollberget Experimental Area in the south (panel b), the distribution of quaternary deposits (panel c), and a close up on the central area, which included sub-catchments C2,C4, C5, C6 and C7, the experimental stream segment (between C5 and C6), and approximately 150 groundwater wells (panel d) 
geography, soil science, ecology, forestry, land-use history, and political science.

Forestry and peatland research began in the area in the 1910s, with the first field station being built in 1923 at the Kulbäcksliden research park (Grip, 2015). Forest regeneration was the primary motivation for establishing the nearby Svartberget research station in the center of the KCS in 1979. The specific questions at that time were primarily related to microclimatic conditions after forest harvesting, nutrient limitation to tree growth, and forest hydrology. Ten years later, the role of acid deposition and natural acidity became the major water related research question at the site (Bishop et al., 1990). The combined focus on climate, forestry, and hydrology resulted in a wide range of high quality field measurements that are now of particular importance for documenting responses to current environmental changes.

\section{1 | Climate}

An overall warming pattern is clear from the long-term air temperature record at Svartberget from 1980 to 2020, but becomes even more visible when extending the time series back to 1891 by using the nearby Stensele site (Figure 2) for extrapolation. Annual air temperature has increased by about $3.0^{\circ} \mathrm{C}$ since 1891 , but the most pronounced increase $\left(2.5^{\circ} \mathrm{C}\right)$ has occurred in the last 40 years (MannKendall tests, $p<0.001$ ), with 2020 by far being the warmest year on record. The seasonal air temperature has increased most rapidly during winter, followed by fall, spring and summer by approximately 0.73 , $0.64,0.62$ and $0.61{ }^{\circ} \mathrm{C}$ per decade, respectively over the 40 years of monitoring (Figure 2b, Mann-Kendall test, $p<0.01$ for all seasons).
Total annual average precipitation equals $623 \mathrm{~mm}$, ranging from 446 (1994) to $918 \mathrm{~mm}$ (1982), with no statistical trend over the last 40 years. Of the precipitation, approximately $30 \%$ arrives as snow. The average snow water equivalents (SWE) for the 40 years of record is $180 \mathrm{~mm}$, ranging from 64 (1996) to 321 (1988) mm. The 40-year average duration of winter snow cover is 167 days, but this has been decreasing over time. During the first decade of measurement, the average date of initial snow cover was in early November; since then, this onset has been delayed by $\sim 0.5$ day year ${ }^{-1}$ (Laudon \& Ottosson Löfvenius, 2016). However, the melting of snow in spring has experienced no significant trend, and on average peaks in late April. The long-term average annual runoff at a forest dominated catchment (C7; Figure 3a) has been $298 \mathrm{~mm}$, with a minimum of $112 \mathrm{~mm}$ (1996) and maximum of $555 \mathrm{~mm}$ (2000) (cf. Teutschbein et al., 2018). The 40-year highest hourly runoff occurred in November 2020.

\section{2 | Land-use history}

Approximately $25 \%$ of the KCS has been protected for research since 1922, whereas the ownership of the remaining area is divided among private individuals and forest companies. Currently, forest covers $87 \%$ of the KCS and is dominated by Scots pine (Pinus sylvestris) (63\%) and Norway spruce (Picea abies) (26\%) with an understory of ericaceous shrubs, mostly bilberry (Vaccinium myrtillus) and lingonberry (Vaccinium vitis-idaea) on moss-mats of Hylocomium splendens and Pleurozium schreberi. Sphagnum spp. together with sparse coverage of sedges and dwarf shrubs dominate on open peatlands, which primarily can be categorized as oligotrophic minerogenic mires.

(b)

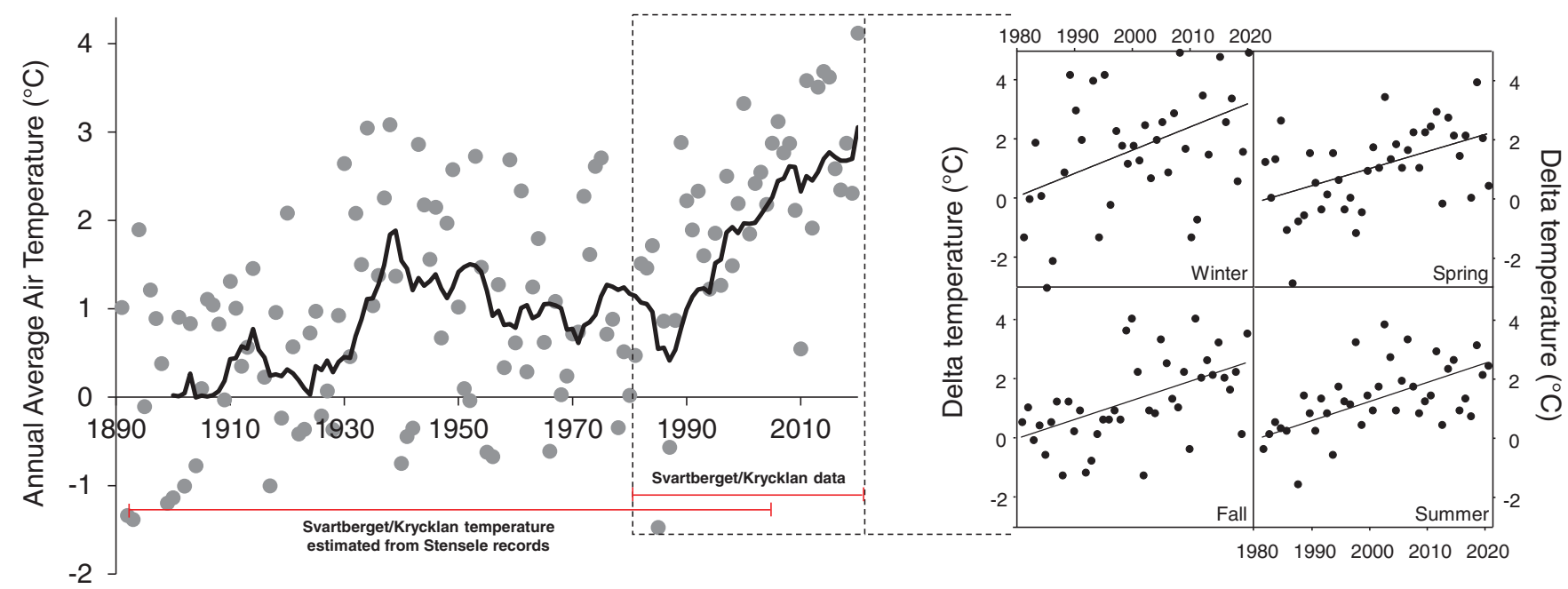

FIG URE 2 Panel a. Mean annual air temperature at Svartberget from 1890-present with 10-year running average (solid line). Data prior to 1980 are modeled from the scaling relationship with a nearby climate station at Stensele (150 km to northeast). The 24 year overlap (1980-2004) in the air temperature records at these two stations yielded a linear correlation with slope $=1.041$, intercept $=-0.008, r^{2}=0.93, p<0.001$, and $\mathrm{RMSE}=2.786$. Panel $\mathrm{b}$ shows the seasonal trends in air temperature from the Svartberget station from 1980 to present 
(a)

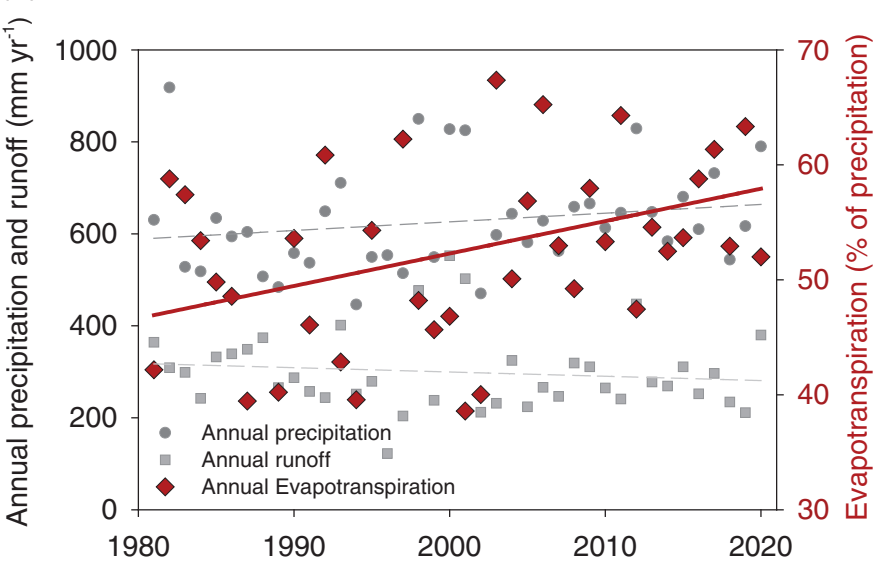

(c)

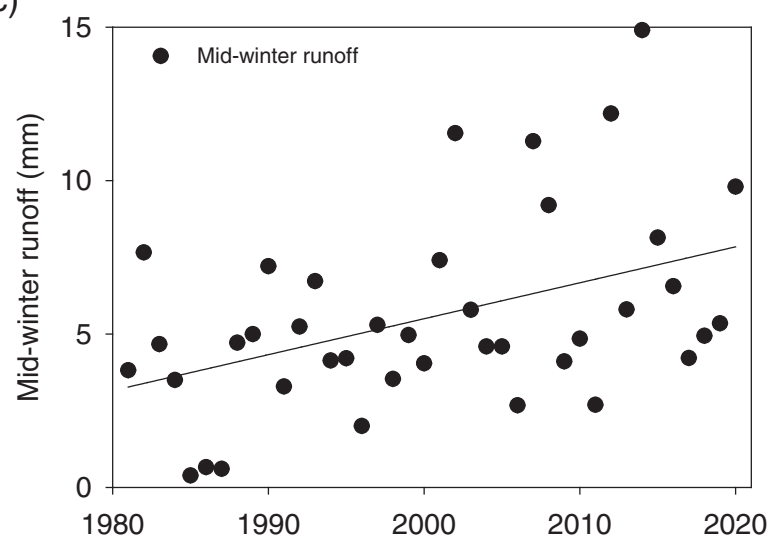

(e)

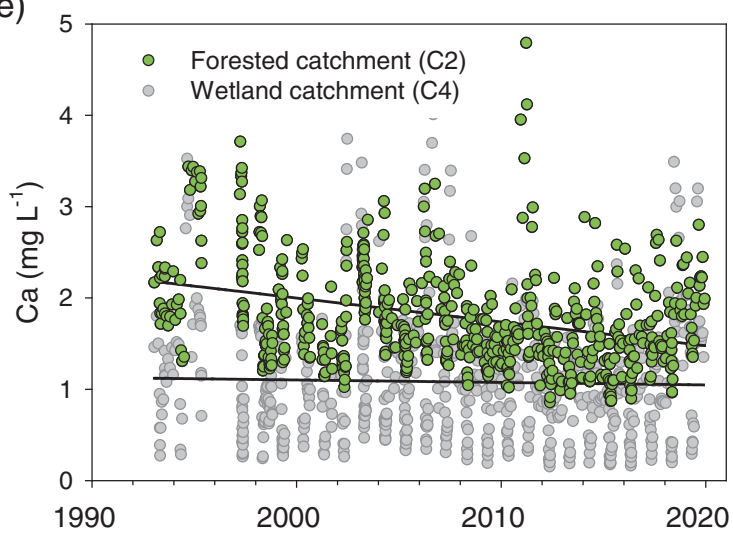

(b)

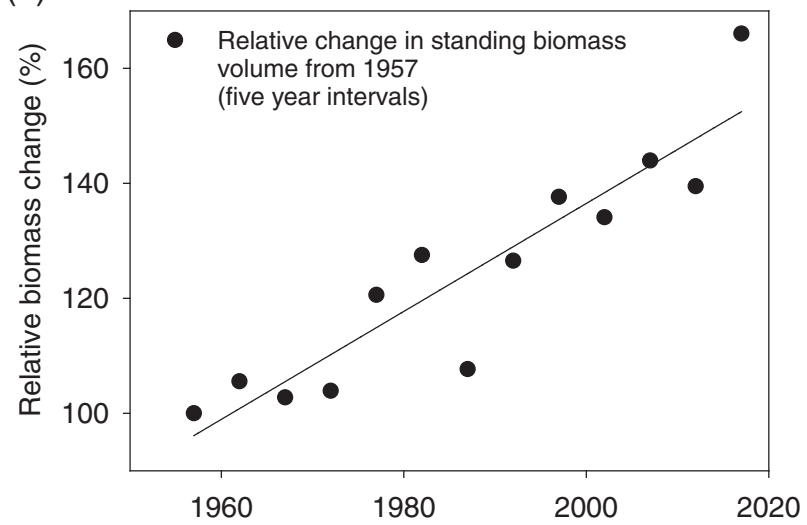

(d)

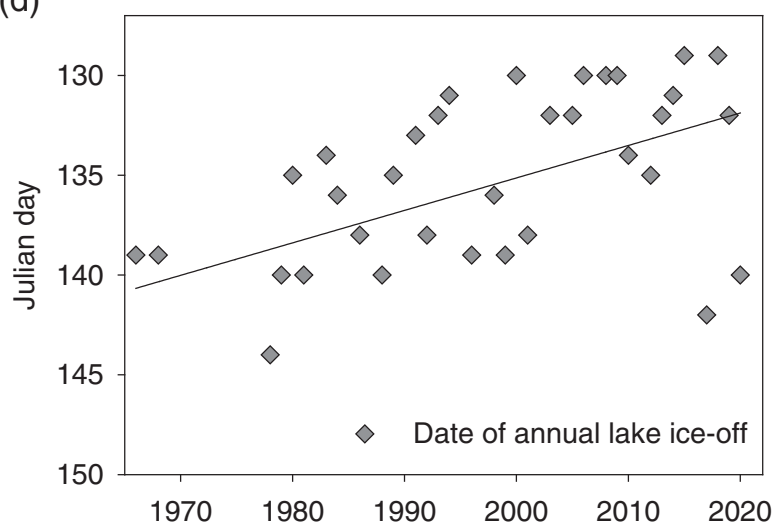

(f)

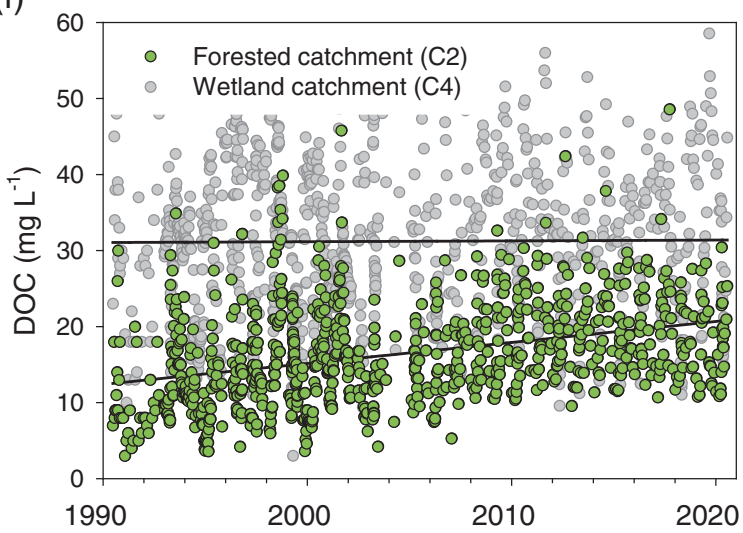

FIGURE 3 Examples changing hydrological and chemical conditions in the Krycklan Catchment Study over the last 30-60 years. These changes include an increase in evapotranspiration ( $\mathrm{ET}$, trend: $+0.3 \%$ year $^{-1}$ ) at the $\mathrm{C} 7 \mathrm{catchment}$ measured as the difference between precipitation and discharge (panel a). Long-term increases in forest biomass in the extended Krycklan area relative to estimates in 1957 (trend: $+1.0 \%$ year $^{-1}$; panel b; Swedish National Forest Inventory, SLU, unpublished data). An increase in mid-winter (March) runoff in the C7 catchment (trend: $+0.1 \mathrm{~L} \mathrm{~s}^{-1}$ year $^{-1}$; panel c). Declines in the timing (date) of lake ice-off in the spring, based on a 55 -year record collected $25 \mathrm{~km}$ north of the Krycklan (trend: -0.2 days year ${ }^{-1}$; Rune Axelsson, unpublished data; panel d). Declining Ca concentrations in a forest-dominated stream (C2; trend: $-0.02 \mathrm{mg} \mathrm{L}^{-1}$ year $^{-1}$ ), but not for an adjacent mire-domminated stream (C4; panel e). Increasing DOC concentrations in same forested stream (C2; trend: $+0.2 \mathrm{mg} \mathrm{L}^{-1}$ year $^{-1}$ ), but not in the mire-dominated counterpart (C4; no trend, panel f). All trends were calculated using Mann Kendall tests

KCS has experienced relatively low levels of direct human influence. The current population of the area is approximately 1.2 people per $\mathrm{km}^{2}$. Historically, the human population was even lower and only hunting, fishing, and reindeer herding occurred before 1750, when the first village settlements were established. Prior to the early 1900 's, peatlands constituted a major source of livelihood for farmers. In the KCS, this meant that up to $22 \%$ of the original peatland area was used for hay harvest on mire meadows (Norstedt et al., 2021), 
whereas only $3 \%$ were drained for more modern agriculture. Presently, only $1 \%$ of the original peatland area is still used for agricultural purposes. Beginning around 1900, mires were drained to enhance forest wood production. As a consequence, about $40 \%$ of the original peatland area is currently forested (Norstedt et al., 2021). In addition, approximately $162 \mathrm{~km}$ of forest drainage ditches can be found within the KCS area (Hasselquist et al., 2020), which can be compared with approximately $180 \mathrm{~km}$ of natural, permanent streams (Ågren et al., 2015). Prior to the 1940 s, selective cutting was the primary method used in forestry. Later, rotation forestry grew to dominate, involving mostly clear-cutting with subsequent planting of conifers (Norstedt \& Laudon, 2019).

\section{3 | Geological and physiographic setting}

The KCS is located in the Svecofennian orogenic belt, which traverses large parts of northern Sweden. The bedrock is dominated by 1.92 $1.87 \mathrm{Ga}$ old migmatised meta-greywacke or paragneiss, which consists of metamorphosed sediments once deposited outside the Achaean Baltic Shield. The numerous hills in the area with peaks up to $400 \mathrm{~m}$ are largely derived from selective weathering of biotiteplagioclase schist in the valleys and more resistant veined gneiss at higher altitudes. Further inland, the meta-sediments are gradually replaced by $1.74-1.82 \mathrm{Ga}$ old granite and granodiorite, which also occur as intrusions in the KCS along with minor intrusions of mafic rocks.

The Quaternary deposits are strongly influenced by the latest glaciation. Drumlins and crag-and-tails are aligned in a SSE direction as the inland ice was moving from NNW. The ice retreated from the area ca. 10200 a BP (Stroeven et al., 2016), leaving up to $30 \mathrm{~m}$ thick till in sheltered areas, but also bare bedrock in more exposed locations. In addition, the large Vindel River Esker passes through the lower parts of the KCS adding large deposits of glaciofluvial material (Figure 1c). The Quaternary deposits are predominately of local origin, displaying a silicate-dominated chemistry with quartz $>$ plagioclase $>K$ feldspar $>a m p h i b o l e s$ as the main minerals (Lampa et al., 2020). At the termination of the deglaciation, approximately half of the KCS was located below the highest postglacial coastline (situated at ca $257 \mathrm{~m}$ above present sea level). This has resulted in locally $>60 \mathrm{~m}$ deep sand and silt sediments that now cover the lower parts of the KCS, deposited by the Vindel River during the course of the isostatic rebound. In areas with low topographic relief, peat has built up, generally forming oligotrophic minerogenic mires.

\section{3 | LONG-TERM ENVIRONMENTAL TRENDS}

The boreal region encompassing the KCS has experienced some strong environmental trends during the last several decades. Changes in climate, land-use, and long-range transport of air pollutants all have had a role to play in explaining some of these decadal changes. Despite having a highly developed research infrastructure in place, the co-occurrence, interaction, and synchronicity of several human interventions complicate our efforts to disentangle the causes-andeffects responsible for the observed changes. However, by combining long-time series, large-scale experiments, and modelling we are now beginning to understand the roles climate change, land-use, and atmospheric pollution have played in the past, as well as to predict their relative influences in the future.

Here we highlight some of the major trends in forest biomass growth, lake ice extent, catchment hydrology, and water quality for the KCS (Figure 3). While some of the trends can be directly related to changes in temperature, such as the increasingly earlier lake iceout, other trends can be linked to atmospheric pollution, namely, the decline in stream calcium that is caused by the recovery from acid deposition (Laudon et al., 2021). Increased forest biomass production, stream water brownification, and increase in ET are likely caused by a combination of interacting factors. Such interactions, and the fact that some catchments respond while adjacent systems do not, call for the need of continued research to disentangle the cause-and-effect mechanisms. In addition, we urgently need to provide predictions for what these large-scale environmental changes will mean for northern environments. This includes understanding the direct and indirect effects on carbon and greenhouse gas (GHG) balances, atmospheric radiative forcing, terrestrial and aquatic biodiversity, water quality, and on the capacity for northern regions to support society. Living up to society's many goals for the region in an environment that is constantly changing, requires maintaining research infrastructures that take a landscape scale perspective and measure the most important processes in the atmosphere, vegetation, soils, bedrock, and water, as well as the interactions between them.

\section{4 | RESEARCH INFRASTRUCTURE}

The ambition of KCS is to take a holistic ecosystem perspective of the boreal landscape to understand, elucidate, and predict the role of internal and external drivers of catchment processes across a range of scales. To do this, we combine state-of-the-art technology to capture various ecosystem processes with traditional research tools and basic environmental monitoring. We focus on processes and dynamics of living and non-living ecosystem compartments, as well as the fluxes of energy, water, carbon, nutrients, metals, and other compounds within and between the atmosphere, lithosphere, cryosphere, and hydrosphere. In the KCS, we do this by combining a large, central, research facility - namely, the ICOS research tower - with supplemental infrastructures distributed across the entire landscape (Figure 4). In addition to these facilities, the KCS also offers a number of large scale and/or long-term experimental facilities. Below we outline some of the most central of these facilities and data.

\section{1 | Surface water program}

The hydrology and water chemistry program has been a central feature of the KCS program since the beginning. The 50 ha C7 catchment 


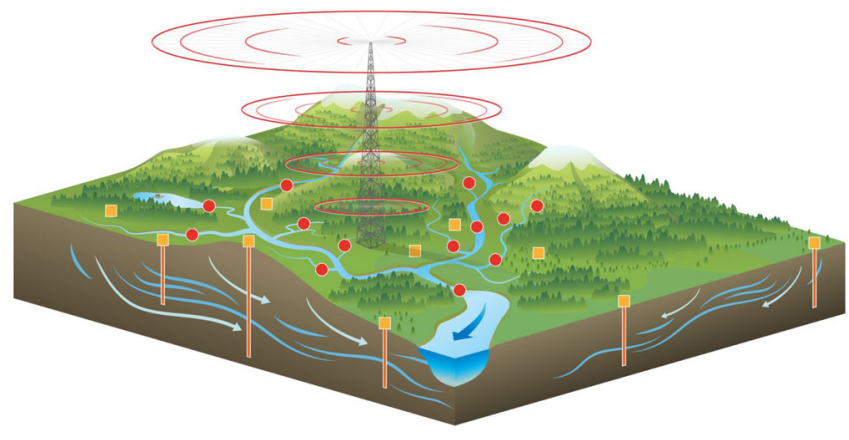

FIGURE 4 Schematic depiction of the major field installations in the KCS, including the stream and groundwater monitoring network, as well as the $150 \mathrm{~m} \mathrm{ICOS}$ tower in the catchment center

(also called Svartberget or Nyänget in earlier work) is located in the central part of the research station and was established in 1980 and marks the start of what today is the KCS. Since 1984, the two subcatchments that feed C7 have also been monitored, one completely forested (Västrabäcken, C2) and the other dominated by a mire (Kallkälsmyren, C4). In 2002, the KCS expanded further to include 11 nested sub-catchments that have been continuously monitored in the 6790 ha Krycklan catchment (including C2, C4 and C7; see Figure 1 and Table 1). Heated huts allow year around measurements at C7 since 1982, at C2 and C4 since 2011, at C5 (a lake outlet) since 2012, and at C13 since 2014. The details of the hydrological monitoring program was presented by Karlsen, Grabs et al. (2016) and Karlsen, Seibert et al. (2016), while additional within lake measurements are being conducted in Stortjärn (Denfeld et al., 2020).

In total, 12 000 stream water samples have been collected and analyzed from KCS stream sites. Regular sampling began at C7 in 1985, at C2 and C4 in 1990, and at most of the remaining sites in 2003 (Table 1). Most samples have been analyzed for basic chemistry $(\mathrm{pH}$, major cation and anions), dissolved and/or total organic carbon (DOC and/or TOC). Absorbance spectra (from 190 to $1100 \mathrm{~nm}$ ) and dissolved inorganic carbon (DIC) have been part of the standard protocol since 2003. On selected samples, analysis of a suite of stable and radioactive isotopes $\left({ }^{18} \mathrm{O}, \mathrm{D},{ }^{14} \mathrm{C},{ }^{13} \mathrm{C},{ }^{15} \mathrm{~N},{ }^{54 / 56} \mathrm{Fe},{ }^{137} \mathrm{Cs}\right.$, ${ }^{206 / 207 / 208} \mathrm{~Pb},{ }^{226} \mathrm{Ra},{ }^{230} \mathrm{Th},{ }^{234 / 238} \mathrm{U}$ ), trace elements (including $\mathrm{Hg}$, $\mathrm{Pb}$, Rare Earth Elements [REE]) and persistent organic pollutants (PCBs, HCB and other) have also been included (see Ingri et al., 2018; Josefsson et al., 2016; Laudon et al., 2011; Lidman et al., 2014; Tiwari et al., 2017).

In addition to the regular sampling program a number of high-frequency, real-time measurements are now being conducted, especially in the central KCS area including streams C2, C4, C5, C6 and C7 (Figure $1 \mathrm{~d}$ ) using carbon dioxide $\left(\mathrm{CO}_{2}\right)$ and dissolved oxygen sensors, and measurements of absorbance spectra (Gomez-Gener et al., 2020; Lupon et al., 2019; Riml et al., 2019). The purpose of these sensors is to capture rates of aquatic metabolism in relation to terrestrial contributions, but also to better understand the rapid, dynamic, and non-linear stream biogeochemical responses to weather and climatic events that cannot be captured by the relatively infrequent sampling program.

\subsection{Climate data program}

As part of a reference monitoring program, above- and below ground climate data have been monitored since 1980 at the Svartberget station following World Metrological Organization (WMO) protocols. In total, approximately 100 meteorological variables are automatically monitored. Another 20 variables are manually observed, including phenological observations.

Precipitation as both rain and snow have been measured as part of the reference climate monitoring program at the Svartberget field station since 1980. Rain and snow chemistry have been sampled since 1983 , with each precipitation event collected and stored as individual samples, composited monthly, and analyzed for chemistry (see Laudon et al., 2021). Snow accumulation and snow density measurements have been monitored approximately weekly since 1980 (Laudon \& Ottosson Löfvenius, 2016).

\subsection{Soil water program}

Soil water from three soil profiles (called the S-transect) located 4, 12 and $22 \mathrm{~m}$ from the C2 stream have been monitored 5-12 times per year since 1995 for water isotopes and water chemistry (Bishop et al., 2004; Blackburn et al., 2017; Lidman et al., 2017; Nyberg et al., 2001). The S-transect is aligned based on topography, following the lateral flowpath of groundwater. Each profile consists of measurements at six soil depths between 5 and $90 \mathrm{~cm}$ using ceramic suction lysimeters (P100). Soil water content using Time-domain reflectometry (TDR) and soil temperatures are measured at the same depths. A similar setup was installed in one of the wetland soils upstream of C4 to monitor soil water chemistry since 1997 using 12 nested wells extending to different depths, ranging from 25 to $350 \mathrm{~cm}$ below the ground surface (Lidman et al., 2013; Sponseller et al., 2018). In 2007, the Riparian Observatory of Krycklan, a complementary set of transects to represent a range of topographic situations was also established (Grabs et al., 2012).

Ten pairs of DRIP (Discrete Riparian Inflow Point) and non-DRIP well transects were established in 2015 in riparian zones in central KCS streams (Figure 1d). Each pair is located adjacent to each other and therefore experience comparable environmental conditions, except for groundwater hydrology. DRIP sites are located on the receiving end of converging groundwater flow paths, and are characterized by shallow water tables, often reaching the soil surface before converging with streams (see Leach et al., 2017). Non-DRIP sites are situated in more elevated, drier riparian areas. Each transect is equipped with three fully screened groundwater wells, situated in riparian (0-3 $\mathrm{m}$ distance from the stream), transition (10 $\mathrm{m}$ distance from the stream), and upland (20 m distance from the stream) areas (Ploum et al., 2020).

\subsection{Groundwater program}

Monitoring of the groundwater $(>2 \mathrm{~m})$ in the KCS has been conducted since 1980 by the Swedish Geological Survey (SGU) as part of their 


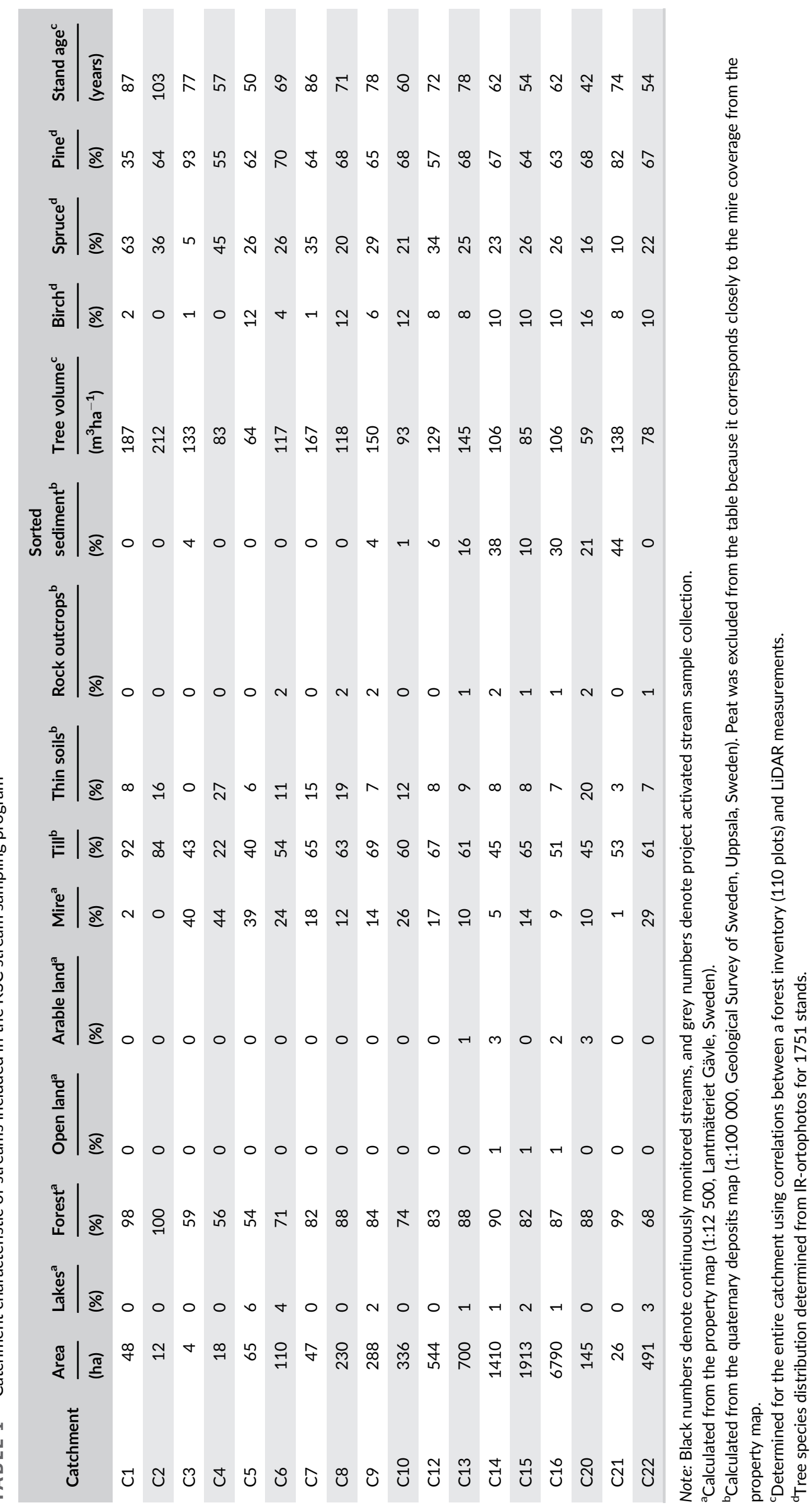


national monitoring. The past decade has seen a continuous expansion of the groundwater well network, with currently over 150 wells within the KCS. With the exception of a $150 \mathrm{~m}$ deep well penetrating the bedrock, these wells are placed in the Quaternary deposits at depths from ca. 2-30 m. Most wells are of piezometer type, to allow the determination of the hydraulic head in given soil layers, as well as the extraction of groundwater samples for chemical and isotopic analyses at specific depths. The wells are primarily distributed in the central parts of the catchment, with well-clusters where the groundwater from different depths at the same location can be investigated (Figure 1d). The purpose of these installations has been to enhance the understanding of deeper groundwater in the landscape, with respect to transit times (Peralta-Tapia et al., 2015), flow pathways (Lidman et al., 2016), residence times (Kolbe et al., 2020), and water chemistry (Klaminder et al., 2011). On-going collaboration with the SGU is aimed at developing a 3D soil map for the entire KCS in order to provide a stronger foundation for further exploration of the links between Quaternary deposits, hydrology, and water quality. The project includes further geophysical investigations of the area, including transient electromagnetics, drilling, and installation of more groundwater wells.

\section{5 | Biosphere-atmosphere exchanges of carbon, water and energy}

A combined atmosphere-ecosystem ICOS station is located in the center of KCS (Figures 1 and 4). ICOS is a pan-European research infrastructure with the mission to produce standardized, high-precision, and long-term observations of greenhouse gases and to facilitate research to understand the carbon cycle (www.icos-cp.eu/). The ICOS Svartberget infrastructure has been in operation since 2014. The atmosphere and ecosystem stations were officially labelled and designated as ICOS Europe stations in 2017 and 2019, respectively. All ICOS data are quality controlled by central thematic centers and made openly available via the ICOS Carbon Portal (https://data.icos-cp.eu/ portal). Data from ICOS Svartberget, as well as from non-ICOS eddy covariance measurements, are frequently used in various global synthesis publications. All data publication at the ICOS Carbon Portal is coordinated with the global Fluxnet data base initiative.

The atmosphere station conducts measurements of $\mathrm{CO}_{2}$, carbon monoxide (CO) and methane $\left(\mathrm{CH}_{4}\right)$ concentrations, as well as of air temperature and humidity at three levels $(35,85,150 \mathrm{~m}$ height). At $150 \mathrm{~m}$, concentrations of ${ }^{14} \mathrm{CO}_{2}$ and ${ }^{13} \mathrm{CO}_{2}$ are also measured with lower time resolution (i.e., by periodic flask sampling). The atmospheric concentration measurements have a footprint of several hundred kilometres and in combination with other atmospheric measurement stations in Northern Europe capture subcontinental scale conditions and processes.

The ecosystem station provides measurements of the biosphereatmosphere exchange of $\mathrm{CO}_{2}$, water (i.e., evapotranspiration), and energy using the eddy covariance (EC) technique. These measurements (conducted at $34.5 \mathrm{~m}$ height) have a footprint of several hundred metres, representing the specific ecosystem conditions in the vicinity of the tower, including catchments $\mathrm{C} 2$ and C7. In addition, key meteorological (i.e., radiation, temperature, wind, humidity, precipitation), phenology, and soil environmental (temperature, moisture, heat flux and water table level) variables are continuously monitored on the tower and along four soil depth profiles, respectively. Permanent sample plots for inventories of tree and understory vegetation biomass, species, leaf area, phenology and leaf chemistry, and litter fall give additional information related to ecosystem properties.

The ICOS infrastructure also serves as a platform for establishing and connecting external research projects. For instance, the installation of two more EC systems at 60 and $85 \mathrm{~m}$ height along the ICOS tower provides additional estimates of $\mathrm{CO}_{2}, \mathrm{CH}_{4}$, water, and energy exchanges at the landscape scale (i.e., few $\mathrm{km}$ radius), roughly spanning the area of the KCS (Chi et al., 2019). Integration of these landscape EC measurements with aquatic fluxes of carbon species via stream runoff has resulted in a first estimate of the net landscape carbon balance (NLCB) for the KCS (Chi et al., 2020). In addition, the combination of EC and sapflow measurements around the ICOS tower has provided an opportunity to partition the forest water cycle components (Kozii et al., 2020). Furthermore, the concentration measurement profile including several levels along the $150 \mathrm{~m}$ tall tower has enabled investigations of atmospheric organic pollutants (Bidleman et al., 2017), as well as water isotope and mercury dynamics. The ICOS tower structure also hosts multispectral sensors, and phenology cameras within the SITES-Spectral infrastructure to collect spectral data for estimating ecosystem vegetation properties at various spatial and temporal scales.

\section{6 | Sapflow measurements}

In spring 2016, a network of Granier sap flow sensors (Granier, 1985) was installed in 70 trees ( 30 P. sylvestris, 30 P. abies and 10 Betula sp.) to continuously measure tree-level transpiration, an integrated measure of whole tree hydraulic stress, in the three tree species that are dominant in Fennoscandian boreal forests. This technique includes a pair of thermocouple sensors that detect changes in the temperature difference $(\Delta T)$ from the baseline ( $\Delta T_{m}$ at zero flow), which in turn reflects the flow rate of water through stems (Granier, 1987). In addition, a field deployed Picarro L2131-i analyzer provides continuous, high temporal resolution isotopic measurements of tree xylem water. Taken together, these measurements provide a unique opportunity to test how changes in environmental conditions affects stand evaporation and tree-level transpiration across a range of temporal scales as well as directly compare the importance of transformations into other water balance components (i.e., streamflow) within a northern boreal headwater catchment.

\section{7 | Terrestrial and stream biology}

Repeated forest and below canopy surveys of 550 permanent $10-\mathrm{m}$ radius plots were conducted in 2016 and 2020. By linking these 


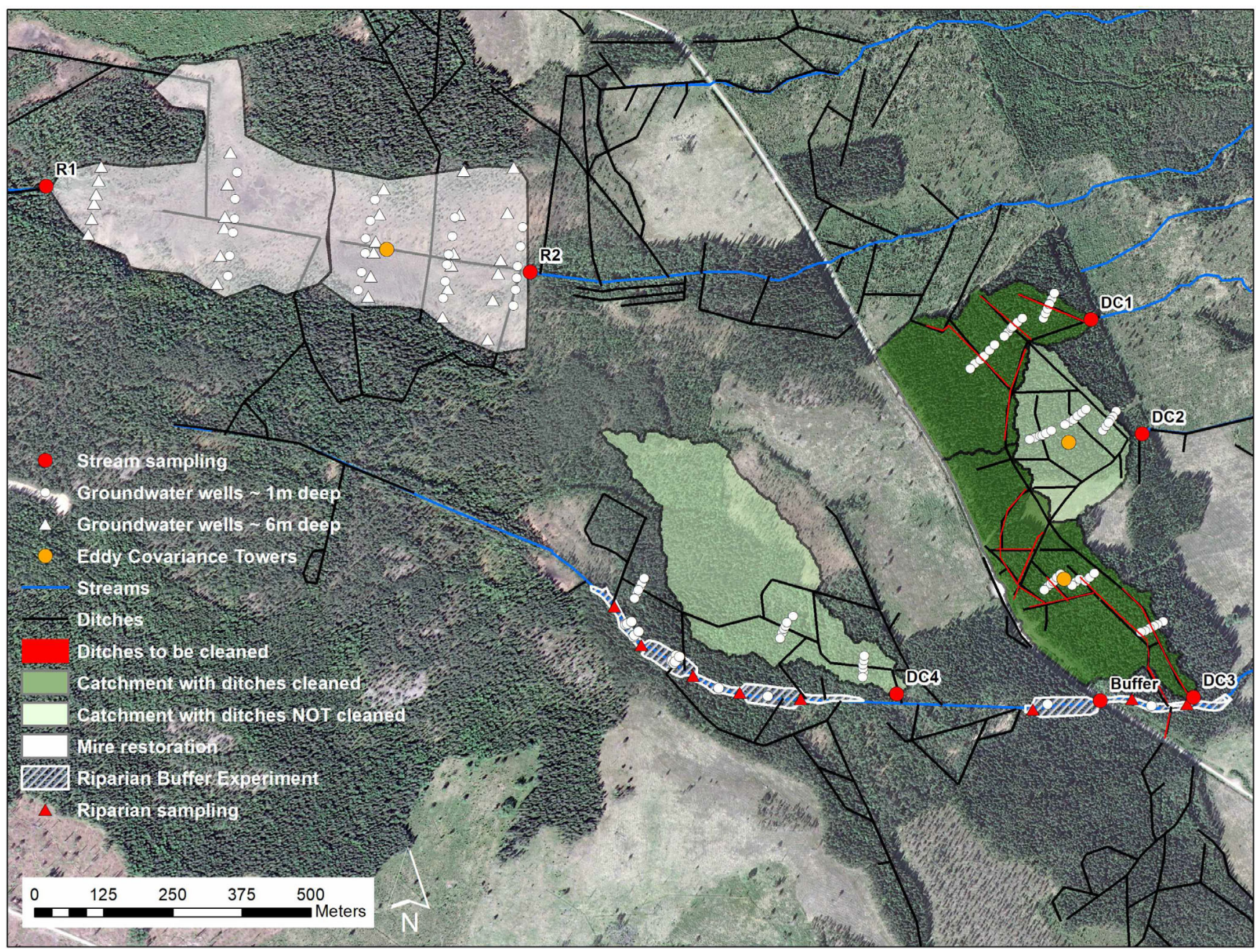

FIGURE 5 The Trollberget Experiment Area (TEA) used to study the effect of wetland restoration, ditch network maintenance and riparian buffer design

surveys with concurrent Lidar scans and soil inventory, the ambition is to develop a mechanistic link between forest growth, soil conditions, and modelled groundwater pathways. A systematic survey of riparian plant communities was conducted in 2013, depicting the relationship between vascular and non-vascular plant diversity with stream size and groundwater flow paths including 32 KCS sites (Kuglerová et al., 2014, 2015).

Macroinvertebrate and stream microbial data have been collected repeatedly from a number of streams within the catchment and used in different contexts (e.g., Burrows et al., 2017; Göthe et al., 2013; Jonsson et al., 2017). Survival experiments on fish (Serrano et al., 2008) and invertebrate population studies (Petrin et al., 2007) have been conducted in several of the monitored streams. In addition, the main stem of the Krycklan river network has been used as an unimpacted (by timber floating) reference site in a number of studies of stream hydrogeomorphology (Polvi et al., 2014), riparian plant diversity and composition (Hasselquist et al., 2015), riparian nutrient cycling (Hasselquist et al., 2017), instream ecosystem functioning (Frainer et al., 2018), and biodiversity (Hasselquist et al., 2018). Since
$2007, C 7$ is also a part of the national freshwater monitoring program under which aquatic macroinvertebrates are annually collected to depict long-term biodiversity trends.

\section{8 | Lidar data}

In addition to the national lidar scans (2010, point density 0.5 points $\mathrm{m}^{-2}$ and 2019, point density 1-2 points $\mathrm{m}^{-2}$ ), KCS has been scanned during different campaigns, allowing for high resolution DEMs down to $0.5 \mathrm{~m}$ resolution and providing detailed tree level data. The first specific scanning was conducted in 2006 with a point density of up to 10 points $\mathrm{m}^{-2}$. In 2008, the KCS was scanned as part of the BIOSAR campaign with the TopEye system S/N 425 mounted on a helicopter, at a flight altitude of $500 \mathrm{~m}$ above ground level for main strips and $250 \mathrm{~m}$ above ground level for cross strips, using an average point density of approximately 5 points $\mathrm{m}^{-2}$ in the main strips and 15 points $\mathrm{m}^{-2}$ in the cross strips. In 2015, the KCS was scanned by Terratec with the Optech Titan $X$ sensor at a flight height around $1000 \mathrm{~m}$ 
giving a point density of on average 20 points $\mathrm{m}^{-2}$. This sensor scanned at 3 wavelengths, $532 \mathrm{~nm}$ (green), 1064 (NIR), and $1550 \mathrm{~nm}$ (SWIR). In 2019, the KCS was scanned with Riegl VQ-1560i-DW $532 \mathrm{~nm}$ (green) and 1064 (NIR) with an average point density of 20 points $\mathrm{m}^{-2}$.

\section{9 $\quad$ Experimental platforms}

Unravelling how the climate, land-use, and other environmental perturbations can affect short and long-term patterns in hydrology, water quality and biodiversity, requires more than just good empirical data from the past and present. It will be equally important to generate data from controlled conditions outside the natural range of variability previously experienced, representing anticipated external forcings in the future. Experimental manipulations in the field are of fundamental importance in this respect, as they can mimick expected extreme conditions and responses to future perturbations. This is needed to enhance our mechanistic understanding and constrain model predictions. The already existing infrastructure and large availability of land for research at the KCS makes large-scale and long-term experiments feasible and relatively simple to conduct.

\subsection{1 | The Trollberget Experimental Area (TEA)}

The Trollberget Experimental Area (TEA) was established in 2018 to test best practices for management of the historical ditch-network and develop new methods to mitigate negative effects on freshwater environments (Figure 5). The $\sim 60$ ha site is located $1 \mathrm{~km}$ from the KCS and drains into the Krycklan River just downstream of $\mathrm{C} 16$. It uses a replicated, catchment-scale approach to address four different research questions concerning forest water management, of which three are assessing the future of historic drainage ditches and one is testing different riparian forest buffer designs. Given the relevance of the topic and the robustness of the experimental set-up, over 25 researchers and projects are now involved in this satellite site (Table 2).

Artificial drainage of peatlands through ditches have dewatered millions of hectares of northern peatlands for forestry. Recent estimates suggest that up to 1 million $\mathrm{km}$ of wetland ditches in Sweden alone have been created (Ågren \& Lidberg, 2019), many of which are now not functioning (Hasselquist et al., 2020). The future fate of these drainage ditches can be to: (1) clean them to ensure resumed drainage, (2) ecologically restore them to a more natural state, or (3) leave them unmanaged. At TEA, we have created a side-by-side comparison of these three different management options with the objective of determining their effects on water quality and quantity as well as their role in altering the landatmosphere greenhouse gas exchanges. Specifically, we have the goal of quantifying the impact of peatland forest harvest, ditch cleaning, and filling-in of ditches (ecological restoration) on dissolved organic matter export and quality, greenhouse gas balance, nutrient and sediment export, export and speciation of mercury, as well as water storage. Here we take a catchment-scale approach to monitoring the dynamics and export from our different treatments. In total, six experimental catchments with an average size of 10 ha are being monitored in TEA, where four catchments in the nearby KCS sites serve as controls.

In addition, TEA includes a riparian buffer experiment with the goal to directly compare the functioning of narrow $(5 \mathrm{~m})$ to wider $(15 \mathrm{~m})$ buffers. In response, we are monitoring nutrient and sediment export, riparian vegetation, and greenhouse gas fluxes in the streams and riparian zone. The unique opportunity of comparing before and after treatment, as well as the differences in responses to buffer widths, will allow for more informed management decisions in the future.

\subsection{2 | A lake -stream experimental facility}

A lake -stream experimental facility in the central part of KCS (Figure 1d) allows for controlled flooding/drought manipulations in a 110 ha catchment system. A water regulating facility at outlet of the lake, just upstream of the sampling site $C 5$, can be used to dam the lake and dry out the $1400 \mathrm{~m}$ stream reach to the downstream sampling site at C6 (Gomez-Gener et al. 2020), or alternatively to trace the source of flood waters downstream (Leach \& Laudon, 2019).

\subsection{3 | Soil frost experiment}

The KCS supports the longest ( $>17$ years) ongoing soil frost manipulations experiment in the world (Campbell \& Laudon, 2019),

TAB LE 2 Catchment characteristics of the Trollberget Experimental Area (TEA)

\begin{tabular}{|c|c|c|c|c|c|c|c|c|c|}
\hline Catchment & Area & Peat & Till & Rock outcrops & Ditch length & Ditch density & Type of & $\begin{array}{l}\text { Length of ditches } \\
\text { managed }\end{array}$ & $\begin{array}{l}\text { \% of ditches } \\
\text { managed }\end{array}$ \\
\hline & (ha) & (\%) & (\%) & (\%) & $(\mathrm{m})$ & $\left(\mathrm{m} \mathrm{ha} \mathrm{a}^{-1}\right)$ & & (m) & (\%) \\
\hline DC1 & 6.7 & 0 & 100 & 0 & 849 & 126 & Cleaned & 658 & 78 \\
\hline DC2 & 4.4 & 0 & 100 & 0 & 1117 & 252 & Left alone & 0 & 0 \\
\hline DC3 & 8.4 & 0 & 100 & 0 & 1780 & 212 & Cleaned & 1077 & 60 \\
\hline DC4 & 10.7 & 34 & 63 & 2 & 795 & 72 & Left alone & 0 & 0 \\
\hline R1- & 47 & 28 & 43 & 18 & 1986 & 42 & Restored & 677 & 34 \\
\hline $\mathrm{R} 2$ & 60 & 23 & 56 & 22 & 5189 & 86 & Restored & 824 & 16 \\
\hline
\end{tabular}


contributing with knowledge critical for interpreting how changes in winter conditions will affect soils and streams. The ongoing experiment has been used to study the effects of soil frost on DOC (Haei et al., 2010, 2012), $\mathrm{CO}_{2}$ emissions (Öquist \& Laudon, 2008), decomposition processes (Kreyling et al., 2013) and root distribution (BlumeWerry et al., 2016).

\subsubsection{Lake mesocosms and experimental flumes}

Although observational studies have tremendously advanced our understanding of freshwater systems, their disadvantages are that many parameters typically correlate and that causality seldom can be determined with any certainty (Downes, 2010). Therefore, experimental facilities are useful to disentangle the effects of individual parameters or their combinations, especially in situations of unimodal responses. In lake Stortjärn, a floating experimental platform consisting of 16 cylindrical $700 \mathrm{~L}$ enclosures submerged in the lake can be used to perform controlled in-site experiments (Urrutia-Cordero et al., 2021). Experiments can be performed concurrently on five lakes across Sweden as part of the SITES-AquaNet infrastructure (https://www.fieldsites.se).

A set of 12 outdoor, experimental flumes (i.e., channels) that are fed by water from an adjacent stream were built in 2020 within the KCS. Each channel is $20 \mathrm{~cm}$ wide, $20 \mathrm{~cm}$ deep, and $15 \mathrm{~m}$ long. Water is pumped into one collector tank and then distributed through four manipulation boxes, allowing four different concurrent treatments with three replicates each. The slope and flow of each channel is adjustable ranging from $0^{\circ}$ to $1.5^{\circ}$ for slope and 0 to $1 \mathrm{~L} \mathrm{~s}^{-1}$ for flow. The channels can also be experimentally heated using warming cables. The bottom substrate in each channel is composed of local, natural gravel and pebbles but can also be manipulated.

In addition to the water and soil experiments, over 50 long-term forestry and biodiversity experiments are ongoing within the KCS area. The oldest of these began in 1911 to test the effect of different provenance of seedlings at this latitude, to better understand plant survival and wood quality. Other experiments include fertilization effects on leaf traits of understory shrubs (Palmroth et al., 2014), the effect of biochar addition on plant communities (Gundale et al., 2016), and thinning and fertilization effects on Scots pine (Valinger et al., 2019).

\subsection{0 | Database and sample archive}

The guiding principles of the KCS research infrastructure are open data, data sharing, and always welcoming new researchers and field studies. The Svartberget research station, run by the Swedish University of Agricultural Sciences Faculty of Forestry offers full access to 2500 ha of land within the KCS for new field studies, and close collaboration with land-owners in the area allows for the establishment of new sampling programs and large scale experiments. The station has approximately 10 full time technical staff year around and many more during snow free season.
For every water sample ever collected within the KCS research program, duplicate samples have been stored at $-18^{\circ} \mathrm{C}$ in acid-washed bottles for chemical analysis, and at $+4^{\circ} \mathrm{C}$, in glass bottles for water isotopes. In total, the Krycklan archive contains over 25000 unique samples. Additionally, the KCS database contains more than 15 million datapoints on water chemistry, and even more data from long-term, high-resolution timeseries on physical parameters. The KCS database builds on a concept we call FAIR \& Square (Laudon \& Taberman, 2016), which is guided by Data FAIR port requirements (https://www. datafairport.org/). While FAIR stands for Findable, Accessible, Interoperable, and Reusable, "Square" symbolizes the importance of acknowledging the original data producer. An important aspect of FAIR \& Square is that we try to provide clear, precise and standardized metadata that can answer questions about "when, where, how, and why" samples have been collected, analyzed and quality controlled.

An important principle in the FAIR \& Square concept is to acknowledge the effort that has gone into acquiring the data being shared. In short we ask users to: (1) always cite the original source of data used, (2) acknowledge other studies that touch on similar aspects that their work builds upon, (3) not distribute data to third parties in order to allow updates/corrections and to avoid spreading erroneous data, and (4) recognize the original data producer properly in acknowledgments if they provided data, or by offering co-authorship if they contributed with significant work, important ideas, and/or helped with essential interpretation.

\section{5 | DIRECTIONS FOR THE FUTURE}

At a time when our environment is under increasing pressure from global change it is alarming that many leading field research infrastructures are under increasing threat to be down-sized or even closed. Failure to recognize and prioritize the value of long term research and monitoring compromises the possibilities that science can contribute to long-lasting solutions. Never before has the need been greater to continue the collection of empirical data that, together with past data, can provide baseline conditions before climate change obscures the clues into how ecosystems functioned without this massive human influence. Understanding the fate of surface and groundwater resources, carbon exchange processes, and threats to biomass production are questions of fundamental importance for the future. Despite this need, the trend in monitoring is going the other way, where empirical studies are declining relative to modelling-based analysis. While modelling will be an important part of environmental science, models must be constrained, tested, and validated by empirical field data to be useful. To cite Sherlock Holmes by Sir Arthur Conan Doyle, "It is a capital mistake to theorize before one has data. Insensibly one begins to twist facts to suit theories, instead of theories to suit facts".

\section{ACKNOWLEDGEMENTS}

KCS has over the years been funded by the Swedish University of Agricultural Sciences, Swedish Research Council (as part of the SITES 
and ICOS Swedish research infrastructures and project funds), FORMAS, Knut and Alice Wallenberg Foundation through BranchPoints and Future Siliviculture, SKB, GRIP-for-LIFE and the Kempe Foundation. We further acknowledge the international networks that have contributed in various ways including eLTER Europe, INTERACT, GLEON etc. KCS also greatly appreciates all the skilled scientists, technicians and students that have contributed in important ways over the years.

\section{ORCID}

Hjalmar Laudon (D) https://orcid.org/0000-0001-6058-1466

\section{REFERENCES}

Ågren, A. M., \& Lidberg, W. (2019). The importance of better mapping of stream networks using high resolution digital elevation models Upscaling from watershed scale to regional and national scales. Hydrology and Earth System Sciences Discussions, 2019, 1-20. https://doi. org/10.5194/hess-2019-34

Ågren, A. M., Lidberg, W., \& Ring, E. (2015). Mapping temporal dynamics in a forest stream network - Implications for riparian forest management. Forests, 6, 2982-3001. https://doi.org/10.3390/ f6092982

Bidleman, T. F., Laudon, H., Nygren, O., Svanberg, S., \& Tysklind, M. (2017). Chlorinated pesticides and natural brominated anisoles in air at three northern Baltic stations. Environmental Pollution, 225, 381-389. https://doi.org/10.1016/j.envpol.2017.02.064

Bishop, K., Buffam, I., Erlandsson, M., Fölster, J., Laudon, H., Seibert, J., \& Temnerud, J. (2008). Aqua Incognita: The unknown headwaters. Hydrological Processes, 22(8), 1239-1242. https://doi.org/10.1002/hyp. 7049

Bishop, K., Seibert, J., Köhler, S., \& Laudon, H. (2004). Resolving the double paradox of rapidly mobilized old water with highly variable responses in runoff chemistry. Hydrological Processes, 18(1), 185-189. https:// doi.org/10.1002/hyp.5209

Bishop, K. H., Grip, H., \& O'neill, A. (1990). The origins of acid runoff in a hillslope during storm events. Journal of Hydrology, 116(1-4), 35-61. https://doi.org/10.1016/0022-1694(90)90114-D

Blackburn, M., Ledesma, J. L. J., Näsholm, T., Laudon, H., \& Sponseller, R. A. (2017). Evaluating hillslope and riparian contributions to dissolved nitrogen $(\mathrm{N})$ export from a boreal forest catchment. Journal of Geophysical Research: Biogeosciences, 122(2), 324-339. https:// doi.org/10.1002/2016JG003535

Blume-Werry, G., Kreyling, J., Laudon, H., \& Milbau, A. (2016). Short-term climate change manipulation effects do not scale up to long-term legacies: Effects of an absent snow cover on boreal forest plants. Journal of Ecology, 104, 1638-1648. https://doi.org/10.1111/1365-2745. 12636

Bradshaw, C. J. A., \& Warkentin, I. G. (2015). Global estimates of boreal forest carbon stocks and flux. Global and Planetary Change, 128, 2430. https://doi.org/10.1016/j.gloplacha.2015.02.004

Burrows, R. M., Laudon, H., McKie, B. G., \& Sponseller, R. A. (2017). Seasonal resource limitation of heterotrophic biofilms in boreal streams. Limnology and Oceanography, 62, 164-176. https://doi.org/10.1002/ Ino.10383

Burt, T. P., \& McDonnell, J. J. (2015). Whither field hydrology? The need for discovery science and outrageous hydrological hypotheses. Water Resources Research, 51, 5919-5928. https://doi.org/10.1002/ 2014WR016839.

Campbell, J. L., \& Laudon, H. (2019). Carbon response to changing winter conditions in northern regions: Current understanding and emerging research needs. Environmental Reviews, 27, 545-566. https://doi.org/ 10.1139/er-2018-0097
Chi, J., Nilsson, M. B., Kljun, N., Wallerman, J., Fransson, J. E. S., Laudon, H., Lundmark, T., \& Peichl, M. (2019). The carbon balance of a managed boreal landscape measured from a tall tower in northern Sweden. Agricultural and Forest Meteorology, 274, 29-41. https://doi. org/10.1016/j.agrformet.2019.04.010

Chi, J., Nilsson, M. B., Laudon, H., Lindroth, A., Wallerman, J., Fransson, J. E. S., Kljun, N., Lundmark, T., Ottosson Löfvenius, M., \& Peichl, M. (2020). The Net Landscape Carbon Balance - Integrating terrestrial and aquatic carbon fluxes in a managed boreal forest landscape in Sweden. Global Change Biology, 26, 2353-2367. https://doi. org/10.1111/gcb.14983

Denfeld, B. A., Lupon, A., Sponseller, R. A., Laudon, H., \& Karlsson, J. (2020). Heterogeneous $\mathrm{CO}_{2}$ and $\mathrm{CH}_{4}$ patterns across space and time in a small boreal lake. Inland Waters, 10(3), 348-359. https://doi.org/ 10.1080/20442041.2020.1787765

Downes, B. J. (2010). Back to the future: Little-used tools and principles of scientific inference can help disentangle effects of multiple stressors on freshwater ecosystems. Freshwater Biology, 55, 60-79. https://doi. org/10.1111/j.1365-2427.2009.02377.x

Fork, M., Sponseller, R. A., \& Laudon, H. (2020). Changing source-transport dynamics drive differential browning trends in a boreal stream network. Water Resources Research, 56(2), e2019WR026336. https://doi. org/10.1029/2019WR026336

Frainer, A., Polvi, L. E., Jansson, R., \& McKie, B. G. (2018). Enhanced ecosystem functioning following stream restoration: The roles of habitat heterogeneity and invertebrate species traits. Journal of Applied Ecology, 55, 377-385. https://doi.org/10.1111/1365-2664.12932

Gomez-Gener, L., Lupon, A., Laudon, H., \& Sponseller, R. A. (2020). Drought-induced biogeochemical shifts in high latitude streams. Nature Communications, 11, 1795. https://doi.org/10.1038/s41467020-15496-2

Göthe, E., Angeler, D. G., \& Sandin, L. (2013). Metacommunity structure in a small boreal stream network. The Journal of Animal Ecology, 82, 449458. https://doi.org/10.1111/1365-2656.12004

Grabs, T., Bishop, K., Laudon, H., Lyon, S. W., \& Seibert, J. (2012). Riparian zone hydrology and soil water total organic carbon (TOC): Implications for spatial variability and upscaling of lateral riparian TOC exports. Biogeosciences, 9, 3901-3916. https://doi.org/10.5194/bg-9-3901-2012

Granier, A. (1985). A new method of sap flow measurement in tree stems. Annales Des Sciences Forestieres, 42, 193-200.

Granier, A. (1987). Evaluation of transpiration in a Douglas-fir stand by means of sap flow measurements. Tree Physiology, 3, 309-319.

Grip, H. (2015). Sweden's first forest hydrology field study 1905-1926: Contemporary relevance of inherited conclusions and data from the Rokliden Hillslope. Hydrological Processes, 29(16), 3616-3631. https:// doi.org/10.1002/hyp.10420

Gundale, M. J., Nilsson, M. C., Pluchon, N., \& Wardle, D. A. (2016). The effect of biochar management on soil and plant community properties in a boreal forest. GCB Bioenergy, 8, 777-789. https://doi.org/10. $1111 /$ gcbb.12274

Haei, M., Öquist, M. G., Buffam, I., Ågren, A., Blomkvist, P., Bishop, K., Ottosson Löfvenius, M., \& Laudon, H. (2010). Cold winter soils enhance dissolved organic carbon concentrations in soil and stream water. Geophysical Research Letters, 37, L08501. https://doi.org/10. 1029/2010GL042821

Haei, M., Öquist, M. G., Ilstedt, U., \& Laudon, H. (2012). The influence of soil frost on the quality of dissolved organic carbon in a boreal forest soil - combining field and laboratory experiments. Biogeochemistry, 107(1-3), 95-106. https://doi.org/10.1007/s10533-010-9534-2.

Hasselquist, E. M., Hasselquist, N. J., Sparks, J. P., \& Nilsson, C. (2017). Recovery of nitrogen cycling in riparian zones after stream restoration using $\delta^{15} \mathrm{~N}$ along a 25-year chronosequence in northern Sweden. Plant and Soil, 410, 423-436. https://doi.org/10.1007/s11104-016-3038-3

Hasselquist, E. M., Mancheva, I., Eckerberg, K., \& Laudon, H. (2020). Policy change implications for forest water protection in Sweden over the 
last 50 years. Ambio, 49, 1341-1351. https://doi.org/10.1007/ s13280-019-01274-y

Hasselquist, E. M., Mancheva, I., Eckerberg, K., \& Laudon, H.(2020). Policy change implications for forest water protection in Sweden over the last 50 years. Ambio, 49(7), 1341-1351. https://doi.org/10.1007/ s13280-019-01274-y.

Hasselquist, E. M., Nilsson, C., Hjältén, J., Jørgensen, D., Lind, L., \& Polvi, L. E. (2015). Time for recovery of riparian plants in restored northern Swedish streams: A chronosequence study. Ecological Applications, 25, 1373-1389. https://doi.org/10.1890/14-1102.1

Hasselquist, E. M., Polvi, L. E., Kahlert, M., Nilsson, C., Sandberg, L., \& McKie, B. G. (2018). Contrasting responses among aquatic organism groups to changes in geomorphic complexity along a gradient of stream habitat restoration: Implications for restoration planning and assessment. Water, 10, 1465. https://doi.org/10.3390/w10101465

Ingri, J., Conrad, S., Lidman, F., Nordblad, F., Engström, E., Rodushkin, I., \& Porcelli, D. (2018). Iron isotope pathways in the boreal landscape: Role of the riparian zone. Geochimica et Cosmochimica Acta, 239, 49-60. https://doi.org/10.1016/j.gca.2018.07.030

Isles, P., Creed, I. F., \& Bergström, A.-. K. (2016). Recent synchronous declines in DIN:TP in Swedish lakes. Global Biogeochemical Cycles, 32, 208-225. https://doi.org/10.1002/2017GB005722

Jonsson, M., Burrows, R. M., Lidman, J., Fältström, E., Laudon, H., \& Sponseller, R. A. (2017). Land use influences macroinvertebrate community composition in boreal headwaters through altered stream conditions. Ambio, 46, 311-323. https://doi.org/10.1007/s13280-0160837-y

Josefsson, S., Bergknut, M., Futter, M. N., Jansson, S., Laudon, H., Lundin, L., \& Wiberg, K. (2016). Persistent organic pollutants in streamwater: Influence of hydrological conditions and landscape type. Environmental Science \& Technology, 50(14), 7416-7424. https://doi. org/10.1021/acs.est.6b00475

Karlsen, R. H., Grabs, T., Bishop, L., Buffam, I., Laudon, H., \& Seibert, J. (2016). Landscape controls on spatiotemporal discharge variability in a boreal catchment. Water Resources Research, 52, 6541-6556. https:// doi.org/10.1002/2016WR019186

Karlsen, R. H., Seibert, J., Grabs, T., Laudon, H., Blomkvist, P., \& Bishop, K. (2016). The assumption of uniform specific discharge: Unsafe at any time? Hydrological Processes, 30, 3978-3988. https://doi.org/10. 1002/hyp.10877

Klaminder, J., Grip, H., Mörth, C. M., \& Laudon, H. (2011). Carbon mineralization and pyrite oxidation in groundwater: Importance for silicate weathering in boreal forest soils and stream base-flow chemistry. Applied Geochemistry, 26, 319-324.

Kolbe, T., Marçais, J., de Dreuzy, J. R., Labasque, T., \& Bishop, K. (2020). Lagged rejuvenation of groundwater indicates internal flow structures and hydrological connectivity. Hydrological Processes, 34(10), 21762189. https://doi.org/10.1002/hyp.13753

Kozii, N., Haahti, K., Tor-ngern, P., Chi, J., Hasselquist, E. M., Laudon, H., Launiainen, S., Oren, R., Peichl, M., Wallerman, J., \& Hasselquist, N. J. (2020). Partitioning growing season water balance within a forested boreal catchment using sap flux, eddy covariance, and a process-based model. Hydrology and Earth System Sciences, 24, 2999-3014. https:// doi.org/10.5194/hess-24-2999-2020

Kreyling, J., Haei, M., \& Laudon, H. (2013). Snow removal reduces annual cellulose decomposition in a riparian boreal forest. Canadian Journal of Soil Science, 93, 427-433. https://doi.org/10.4141/cjss2012-025

Kuglerová, L., Jansson, R., Ågren, A., Laudon, H., \& Malm-Renöfält, B. (2014). Groundwater discharge creates hotspots of riparian plant species richness in a boreal forest stream network. Ecology, 95, 715-725. https://doi.org/10.1890/13-0363.1

Kuglerová, L., Jansson, R., Sponseller, R. A., Laudon, H., \& MalmRenöfält, B. (2015). Local and regional processes determine plant species richness in a river-network metacommunity. Ecology, 96, 381391. https://doi.org/10.1890/14-0552.1
Lampa, M. E., Sverdrup, H. U., Bishop, K. H., Belyazid, S., Ameli, A., \& Kohler, S. J. (2020). Catchment export of base cations: Improved mineral dissolution kinetics influence the role of water transit time. Soil, 6 (1), 231-244. https://doi.org/10.5194/soil-6-231-2020

Laudon, H., Berggren, M., Ågren, A., Buffam, I., Bishop, K., Grabs, T., Jansson, M., \& Köhler, S. (2011). Patterns and dynamics of dissolved organic carbon (DOC) in boreal streams: The role of processes, connectivity, and scaling. Ecosystems, 14, 880-893. https://doi.org/10. 1007/s10021-011-9452-8

Laudon, H., \& Ottosson Löfvenius, M. (2016). Adding snow to the picture - Providing complementary winter precipitation data to the Krycklan catchment study database. Hydrological Processes, 30, 2413-2416. https://doi.org/10.1002/hyp.10753

Laudon, H., Spence, C., Buttle, J., Carey, S. K., McDonnell, J. J., McNamara, J. P., Soulsby, C., \& Tetzlaff, D. (2017). Save northern high-latitude catchments. Nature Geoscience, 10, 324-325. https:// doi.org/10.1038/ngeo2947Laudon

Laudon, H., \& Sponseller, R. A. (2018). How landscape organization and scale shape catchment hydrology and biogeochemistry: Insights from a long-term catchment study. Wiley Interdisciplinary Reviews: Water, 5, e1265. https://doi.org/10.1002/wat2.1265

Laudon, H., Sponseller, R. A., \& Bishop, K. (2021). From legacy effects of acid deposition in boreal streams to future environmental threats. Environmental Research Letters, 16, 015007. https://doi.org/10.1088/ 1748-9326/abd064

Laudon, H., \& Taberman, I. (2016). Data rules: From personal belonging to community goods. Hydrological Processes, 30, 1978-1981. https://doi. org/10.1002/hyp.10811

Laudon, H., Taberman, I., Ågren, A., Futter, M., Ottosson-Löfvenius, M., \& Bishop, K. (2013). The Krycklan Catchment Study-A flagship infrastructure for hydrology, biogeochemistry, and climate research in the boreal landscape. Water Resources Research, 49, 7154-7158. https:// doi.org/10.1002/wrcr.20520

Leach, J. A., \& Laudon, H. (2019). Headwater lakes and their influence on downstream discharge. Limnology and Oceanography Letters, 4, 105112. https://doi.org/10.1002/lol2.10110

Leach, J. A., Lidberg, W., Kuglerov, L., Peralta-Tapia, A., Ågren, A., \& Laudon, H. (2017). Evaluating topography-based predictions of shallow lateral groundwater discharge zones for a boreal lake-stream system. Water Resources Research, 53, 5420-5437. https://doi.org/10. 1002/2016WR019804

Lidman, F., Boily, Å., Laudon, H., \& Köhler, S. J. (2017). From soil water to surface water - How the riparian zone controls element transport from a boreal forest to a stream. Biogeosciences, 14, 3001-3014. https://doi.org/10.5194/bg-14-3001-2017

Lidman, F., Köhler, S., Mörth, C. M., \& Laudon, H. (2014). Metal transport in the boreal landscape - the role of wetlands and the affinity for organic matter. Environmental Science \& Technology, 48, 3783-3790. https://doi.org/10.1021/es4045506

Lidman, F., Peralta-Tapia, A., Vesterlund, A., \& Laudon, H. (2016). ${ }^{234} \mathrm{U} /{ }^{238} \mathrm{U}$ in a boreal stream network - Relationship to hydrological events, groundwater and scale. Chemical Geology, 420, 240-250. https://doi.org/10.1016/j.chemgeo.2015.11.014

Lidman, F., Ramebäck, H., Bengtsson, Å., \& Laudon, H. (2013). Distribution and transport of radionuclides in a boreal mire - Assessing past, present and future accumulation of uranium, thorium and radium. Journal of Environmental Radioactivity, 121, 87-97. https://doi.org/10.1016/j. jenvrad.2012.06.010

Loisel, J., Yu, Z., Beilman, D. W., Camill, P., Alm, J., Amesbury, M. J., Anderson, D., Andersson, S., Bochicchio, C., Barber, K., Belyea, L. R., Bunbury, J., Chambers, F. M., Charman, D. J., de Vleeschouwer, F., Fiałkiewicz-Kozieł, B., Finkelstein, S. A., Gałka, M., Garneau, M., ... Zhou, W. (2014). A database and synthesis of northern peatland soil properties and Holocene carbon and nitrogen accumulation. The Holocene, 24 (9), 1028-1042. https://doi.org/10.1177/0959683614538073 
Lupon, A., Denfeld, B. A., Laudon, H., Leach, J., Karlsson, J., \& Sponseller, R. A. (2019). Groundwater inflows control patterns and sources of greenhouse gas emissions from streams. Limnology and Oceanography, 64, 1545-1557. https://doi.org/10.1002//no. 11134

Norstedt, G., Hasselquist, E. M., \& Laudon, H. (2021). From haymaking to wood production: Past use of mires in northern Sweden affect current ecosystem services and function. Rural Landscapes: Society, Environment, History, 8(1), 2. https://doi.org/10.16993/rl.70

Norstedt, G., \& Laudon, H. (2019). Krycklan: Markanvändning från forntid till nutid (in Swedish). Sveriges Lantbruksuniversitet. Retrieved from https://pub.epsilon.slu.se/18715

Nyberg, L., Stähli, M., Mellander, P. E., \& Bishop, K. H. (2001). Soil frost effects on soil water and runoff dynamics along a boreal forest transect: 1. Field investigations. Hydrological Processes, 15, 909-926.

Öquist, M. G., \& Laudon, H. (2008). Winter soil-frost conditions in boreal forests control growing season soil $\mathrm{CO}_{2}$ concentration and its atmospheric exchange. Global Change Biology, 14, 1-9. https://doi.org/10. 1111/j.1365-2486.2008.01669.x

Palmroth, S., Holm Bach, L., Nordin, A., \& Palmqvist, K. (2014). Nitrogenaddition effects on leaf traits and photosynthetic carbon gain of boreal forest understory shrubs. Oecologia, 175, 457-470. https://doi.org/ 10.1007/s00442-014-2923-9

Peralta-Tapia, A., Sponseller, R. A., Ågren, A., Tetzlaff, D., Soulsby, C., \& Laudon, H. (2015). Scale-dependent groundwater contributions influence patterns of winter baseflow stream chemistry in boreal catchments. Journal of Geophysical Research: Biogeosciences, 120(5), 847858. https://doi.org/10.1002/2014JG002878

Petrin, Z., Laudon, H., \& Malmqvist, B. (2007). Does freshwater macroinvertebrate diversity along a $\mathrm{pH}$-gradient reflect adaptation to low pH? Freshwater Biology, 52, 2172-2183. https://doi.org/10.1111/ j.1365-2427.2007.01845.x

Ploum, S. W., Laudon, H., Peralta-tapia, A., \& Kuglerová, L. (2020). Are dissolved organic carbon concentrations in riparian groundwater linked to hydrological pathways in the boreal forest? Hydrology and Earth System Sciences, 24, 1709-1720. https://doi.org/10.5194/hess-24-17092020

Polvi, L. E., Nilsson, C., \& Hasselquist, E. M. (2014). Potential and actual geomorphic complexity of restored headwater streams in northern Sweden. Geomorphology, 210, 98-118. https://doi.org/10.1016/j. geomorph.2013.12.025.

Riml, J., Campeau, A., Bishop, K., \& Wallin, M. B. (2019). Spectral decomposition reveals new perspectives on $\mathrm{CO}_{2}$ concentration patterns and soil-stream linkages. Journal of Geophysical Research: Biogeosciences, 124(10), 3039-3056. https://doi.org/10.1029/2018JG004981

Serrano, I., Buffam, I., Palm, D., Brännäs, E., \& Laudon, H. (2008). Thresholds for survival of brown trout (Salmo trutta) embryos and juveniles during the spring flood acid pulse in DOC-rich streams. Transactions of the American Fisheries Society, 137, 1363-1377.

Song, J., Wan, S., Piao, S., Knapp, A. K., Classen, A. T., Vicca, S., Ciais, P., Hovenden, M. J., Leuzinger, S., Beier, C., Kardol, P., Xia, J., Liu, Q.,
Ru, J., Zhou, Z., Luo, Y., Guo, D., Adam Langley, J., Zscheischler, J., ... Zheng, M. (2019). A meta-analysis of 1,119 manipulative experiments on terrestrial carbon-cycling responses to global change. Nature Ecology \& Evolution, 3, 1309-1320. https://doi.org/10.1038/s41559-0190958-3

Spence, C., Kokelj, S. V., Kokelj, S. A., McCluskie, M., \& Hedstrom, M. (2015). Evidence of a change in water chemistry in Canada's subarctic associated with enhanced winter streamflow. Journal of Geophysical Research - Biogeosciences, 113-127, 120-127. https://doi.org/10. 1002/2014JG002809

Sponseller, R. A., Blackburn, M., Nilsson, M., \& Laudon, H. (2018). Headwater mires constitute a major source of nitrogen $(\mathrm{N})$ to surface waters in the boreal landscape. Ecosystems, 21(1), 31-44. https://doi.org/10. 1007/s10021-017-0133-0

Stroeven, A. P., Hättestrand, C., Kleman, J., Heyman, J., Fabel, D., Fredin, O., ... Jansson, K. N. (2016). Deglaciation of fennoscandia. Quaternary Science Reviews, 147, 91-121. https://doi.org/10.1016/j. quascirev.2015.09.016

Tetzlaff, D., Carey, S. K., McNamara, J. P., Laudon, H., \& Soulsby, C. (2017). The essential value of long-term experimental data for hydrology and water management. Water Resources Research, 53, 2598-2604. https://doi.org/10.1002/2017WR020838

Teutschbein, C., Grabs, T., Laudon, H., Karlsen, R. H., \& Bishop, K. (2018). Simulating streamflow in ungauged basins under a changing climate: The importance of landscape characteristics. Journal of Hydrology, 561, 160-178. https://doi.org/10.1016/j.jhydrol.2018.03.060

Tiwari, T., Buffam, I., Sponseller, R. A., \& Laudon, H. (2017). Inferring scaledependent processes influencing stream water chemistry from headwater to sea. Limnology and Oceanography, 62, S58-S70. https://doi. org/10.1002/Ino.10738

Urrutia-Cordero, U. P., Langenheder, S., Striebel, M., Eklöv, P., Angeler, D. G., Bertilsson, S., Csitári, B., Hansson, L.-A., Kelpsiene, E., Laudon, H., Lundgren, M., Osman, O. A., Parkefelt, L., \& Hillebran, H. (2021). Functionally reversible impacts of disturbances on lake food webs linked to spatial and seasonal dependencies. Ecology, 102, e03283. https://doi.org/10.1002/ecy.3283

Valinger, E., Sjögren, H., Nord, G., \& Cedergren, J. (2019). Effects on stem growth of Scots pine 33 years after thinning and/or fertilization in northern Sweden. Scandinavian Journal of Forest Research, 34, 33-38. https://doi.org/10.1080/02827581.2018.1545920

How to cite this article: Laudon $\mathrm{H}$, Hasselquist EM, Peichl M, et al. Northern landscapes in transition: Evidence, approach and ways forward using the Krycklan Catchment Study. Hydrological Processes. 2021;35:e14170. https://doi.org/10. 1002/hyp.14170 